\title{
IMAGENS DISRUPTIVAS: ELEMENTOS SURREALISTAS NA CONCEPÇÃO DE HISTÓRIA DE WALTER BENJAMIN
}

\author{
Francisco De Ambrosis Pinheiro Machado ${ }^{1}$
}

\begin{abstract}
Resumo: No Manifesto surrealista, de 1924, Breton explicita o produto da atividade surrealista como uma "luz de imagem", gerado pela aproximaçấo involuntária de duas realidades distantes. Essa estrutura dupla da imagem surrealista tem um caráter disruptivo, que rompe com a nossa percepçáo da realidade cotidiana. Com isso, abre-se a possibilidade de um espaço para a crítica social e histórica, bem como para uma intervenção estético-política justamente em uma sociedade na qual as formas tradicionais de crítica parecem estar neutralizadas. Essa experiência surrealista e esse espaço aberto por ela Walter Benjamin caracteriza respectivamente com a fórmula "iluminação profana" e "espaço de imagem" (Bildraum). Ambos apresentam uma grande semelhança com alguns pontos e consequências, em seus conceitos, tanto de "imagem do pensamento", como de "imagem dialética", sobretudo na medida em que esses conceitos também são formulados em meio à crise cultural da sociedade europeia, nos 1920, e buscam uma saída revolucionária para a mesma. Trata-se de investigar aqui, por meio de uma análise comparativa dessas concepçóes de imagem, até onde vai a influência e a relevância do surrealismo para o pensamento figurativo-dialético de Benjamin e para sua compreensão da história.
\end{abstract}

Palavras-chaVe: Luz de imagem. Imagem de pensamento. Imagem dialética. Walter Benjamin. Surrealismo.

Para Celso Favaretto

\section{INTRODUÇÃo}

A recepção da teoria da história de Walter Benjamin, especialmente desde 1950, se constitui entre duas grandes linhas, a teológica e a marxista, que respectivamente tendiam, não sem polarizaçóes, tanto entre elas quanto dentro delas, a despolitizar ou a politizar excessivamente seu pensamento. A primeira recorre mais a sua obra de juventude (até 1924), a qual tinha um

${ }^{1}$ Professor adjunto da Universidade Federal de São Paulo, São Paulo, SP - Brasil (DD https://orcid. org/0000-0001-8458-627X Email: fapmachado@unifesp.br

http://doi.org/10.1590/0101-3173.2020.v43n2.03.p39

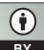


caráter teológico-metafísico; a segunda destaca antes a sua obra de maturidade, que se aproxima do materialismo histórico. Nessas duas linhas, no entanto, deu-se pouca atenção à relação da teoria da história de Benjamin com as vanguardas, em geral, e com o surrealismo, em particular. Somente a partir dos anos 1990 é que essa tendência começa efetivamente a mudar, permitindo perceber o quanto a presença de elementos da experiência dos surrealistas, em paralelo com o modelo do messianismo judaico, no pensamento de Benjamin, também possibilita explicar a peculiaridade histórico-antropológica de seu materialismo, bem como sua crítica ao progresso. $\mathrm{O}$ presente artigo procura explicitar essa relação de Benjamin com o surrealismo, partindo do diagnóstico de época e do conceito de imagem no próprio surrealismo, para confrontá-lo com o modo como Benjamin caracteriza, se aproxima e se distancia dessa experiência de vanguarda.

No Manifesto surrealista, de 1924, Breton explicita o produto da atividade surrealista como uma "luz de imagem", gerado pela aproximação involuntária de duas realidades distantes. Essa estrutura dupla da imagem surrealista tem um caráter disruptivo, que rompe com a nossa percepção da realidade cotidiana. Com isso, abre-se a possibilidade de um espaço para a crítica social e histórica, bem como para uma intervenção estético-política justamente em uma sociedade na qual as formas tradicionais de crítica parecem estar neutralizadas. Essa experiência surrealista e esse espaço aberto por ela Walter Benjamin caracteriza, respectivamente, com a fórmula "iluminação profana" e "espaço de imagem" (Bildraum). Ambos apresentam uma grande semelhança com alguns pontos e consequências, em seus conceitos, tanto de "imagem do pensamento" como de "imagem dialética", sobretudo na medida em que esses conceitos também são formulados em meio à crise cultural da sociedade europeia, nos 1920, e buscam uma saída revolucionária para a mesma. Trata-se de investigar aqui, por meio de uma análise comparativa dessas concepçôes de imagem, até onde vai a influência e a relevância do surrealismo para o pensamento figurativo-dialético de Benjamin e para sua compreensão da história.

\section{1 “LuZ DE IMAGEM" OU A IMAGEM SURREALISTA}

Para tratar da definição de imagem surrealista, recorrerei especialmente ao Manifesto do surrealismo, de 1924, onde Breton fixa as primeiras bases desse movimento que se desenvolvia já há alguns anos na esteira do, mas também 
em oposição ao Dadaísmo. A tensão argumentativa geral desse Manifesto se estrutura a partir do diagnóstico de perda de sentido da existência em função do fechamento da vida, limitação da experiência e redução do pensamento, no mundo moderno, decorrentes do fato de estes se aterem somente ao que é útil e às regras da lógica e, com isso, terem banido a imaginação de seus horizontes. A alternativa surrealista para esse estado é a revalorização da imaginação ou da fantasia ${ }^{2}$, não só a poética, mas também a que opera no delírio, no sonho, na embriaguez, no jogo infantil, na paixão amorosa, no maravilhamento. Daí o papel central que o conceito de imagem, como produto da imaginaçáo, ganha aqui.

O diagnóstico crítico da sociedade que Breton elabora, nesse manifesto, é drástico. O "homem sem imaginação", podemos dizer, sem espírito, descrito nos parágrafos iniciais do Manifesto, náo acredita mais na vida, pois limita sua crença somente à dita "vida real" (vie réelle), não vendo nas coisas mais do que sua utilidade cotidiana e pragmática. O homem é, para Breton (2001, p. 15; 1963, p. 11), um "sonhador definitivo" (rêveur définitif), mas, ao abandonar a imaginaçáo ilimitada, característica da infância, em troca de um pouco de realidade útil, termina sendo ele mesmo abandonado pela imaginação e lançado num "destino sem luz" (destin sens lumière) (BRETON, 1963, p. 12). Perde a razão de viver e não está mais à altura do amor: "E a causa disso é que, já agora, ele pertence de corpo e alma a uma imperiosa necessidade prática, que não admite ser esquecida. A todos os seus gestos faltará amplidão; a todas as ideias envergadura" (BRETON, 2001, p. 16).

Homem plano, pequeno, resignado. Mais do que isso, sem liberdade, porque "somente a imaginaçáo é capaz de mostrar-me aquilo que pode ser" (BRETON, 2001, p. 17). Ou seja, sem ela, não se pode ir além daquilo que é dado por real, positivo, não se pode nada a não ser curvar-se ao pré-estabelecido, a uma destinação heterônoma e obscura. Esse motivo justifica, para Breton, entregar-se, anticartesianamente, à imaginaçáo sem temer o engano, o erro, nem mesmo a loucura, a qual, no limite, são até desejáveis. Isso porque, em primeiro lugar, erro é condição para o bem. Em segundo, os loucos, apesar de serem vítimas da imaginação, não fossem alguns atos repreensíveis que os levam a ser internados, detêm uma liberdade invejável, têm prazer com suas alucinações, mesmo que outros não vejam o valor destas, além de serem

2 Peter Bürger ressalta que Breton, como o dadaísta Tristan Tzara, recusa a lógica, mas, ao contrário deste, sua recusa não é absoluta: dirige-se antes à hegemonia ou redução das possibilidades do pensamento à lógica e propóe a valorização de outra faculdade do pensamento, a imaginação, esta, sim, capaz de resolver os problemas mais importantes da vida (BÜRGER, 1996, p. 53-54). 
honestos e inocentes em suas ilusóes. Os loucos seriam, portanto, os antípodas dos homens rasos e sem imaginação, inclusive, moralmente superiores. A figura do louco é, por isso, muito próxima do poeta sonhador, que Breton esboça, no decorrer do manifesto.

É nesse sentido, também, que Breton critica a literatura produzida pelo homem sem imaginação. $\mathrm{O}$ alvo principal dessa crítica é o que define como atitude realista (entre outros, a de um Anatole France). Literatura de inspiração positivista, igualmente sem profundidade e hostil ao espírito, que cede ao gosto mais chão do público, resultando em um sem número de romances prolixos. $\mathrm{O}$ positivismo destes se manifesta na predominância de frases meramente informativas e insossas, do tipo: "A marquesa saiu às cinco horas"(BRETON, 2001, p. 19), ou em descrições insignificantes e enfadonhas, as quais, segundo Breton, "mais não são que imagens de catálogo sobrepostas" (BRETON, 2001, p. 20), como a seguinte passagem de Crime e castigo, de Dostoievski: "O pequeno cômodo onde o rapaz foi introduzido tinha paredes forradas de papel amarelo: havia gerânios e cortinas de musselina nas janelas; o sol poente lançava uma luz crua sobre as coisas [...] O aposento não tinha nada de especial" (BRETON, 2001, p. 20).

Vale a pena retermos esses exemplos citados por Breton, pois se constituem no oposto da imagem surrealista que será apresentada mais adiante e que nos interessa explicitar. Tais frases e descriçôes puramente informativas, quase jornalísticas, são vazias, já que não saem do lugar comum, são escolares, exteriores e sem investimento de qualquer sentimento. Daí a recusa de Breton em entrar no interior do aposento descrito objetiva e positivisticamente por Dostoievski e desejar, polemicamente, que se cale "quem cessou de sentir"(BRETON, 1963, p. 16) ${ }^{3}$.

À objetividade vazia dessas frases e descrições corresponde a trajetória linear dos respectivos heróis, os quais, por terem seu caráter definido de antemão pelo autor, agem de modo previsível, revelando sempre aquele "tipo humano formado" (BRETON, 1963, p. 17). Enquanto tipos, são personagens sem singularidade e diversidade, resultantes das categorias da razáo objetiva, analítica, da "intratável mania que consiste em reduzir o desconhecido ao conhecido, ao classificável”, em que "o desejo de análise prevalece sobre os sentimentos” (BRETON, 2001, p. 22). Por isso, busca-se explicar e especular

\footnotetext{
3 Ver também: Breton (2001, p. 21). Note-se que Breton, logo em seguida a essa afirmação, ressalta que não reprova a falta de originalidade enquanto tal, porque também ele é sujeito a ela; no entanto, não tenta mostrar para os outros os momentos nulos de sua vida.
} 
sobre as açôes dos heróis, dar-lhes uma lógica, o que, para Breton, é ocioso e antes um enfraquecimento dessas açóes, pois, segundo ele, "todo ato traz em si sua justificação" (BRETON, 2001, p. 22).

Essa literatura sem imaginação espelha, assim, um mundo submetido ao reinado da lógica, que só pode resolver problemas destituídos de importância. Mundo do racionalismo absoluto, de um positivismo que nos limita a fatos de uma experiência estreita, pois restrita à utilidade imediata e a uma realidade sumária, que não abrange de modo suficiente as questôes mais profundas do sentido da vida e das açôes humanas nas quais estấo em jogo não só cálculos e previsões racionais, mas, sobretudo, desejos, utopias, paixôes. Essa é, para Breton, a miséria a que fomos conduzidos em nome do progresso e da civilização, em função dos quais se baniu do espírito tudo o que pode ser taxado de superstição, quimera, fantasia, sonho (BRETON, 1963, p. 19; 2001, p. 23).

Nisso consistiria, ainda, o fundo da crise cultural da sociedade europeia do pós-I Guerra Mundial, porque esta se constrói a partir daquele homem sem imaginaçáo, que nega sua infância; sem liberdade, uma vez que tem pânico da loucura; pobre em experiências vitais, pois estas implicam investimento dos sentimentos. Homem sem a mínima sensibilidade desinteressada ou amplidão da visão poética; homem que resolve de maneira eficaz e racional os problemas práticos da vida cotidiana, produz romances em abundância e pode até destruir o mundo e a própria vida, como a Primeira Guerra mostrou de forma mais candente, mas é incapaz de dar um sentido próprio a sua vida ou transformar-se a si mesmo para chegar a tal.

Maurice Nadeau (2008, p. 14-15), em sua História do surrealismo, escrita em 1944, diagnostica a situação de modo semelhante:

No Armistício, a situação social e política da Europa é excepcional. Teoricamente há dois campos: o dos vencedores e o dos vencidos, mas os primeiros se encontram numa miséria um pouco menor do que os segundos. Penúria não apenas material, mas total, e já colocando, após quatro anos de matanças e destruiçóes de toda espécie, a questão da confiança no regime. Por que isto? Tantos meios gigantescos para acabar numa retificação de fronteiras, na conquista de novas saídas para uns, na sua perda para outros, no roubo de colônias já roubadas? É realmente nesta desproporção entre os meios e os fins que se manifesta a loucura do sistema. Um regime incapaz de disciplinar suas energias para outra coisa que náo o enfraquecimento e a destruição do homem foi à falência. Falência igualmente das elites que em todos os países aplaudem o massacre generalizado, engenhando-se para 
encontrar medidas capazes de fazê-lo perdurar. Falência da ciência, cujas mais belas descobertas residem na qualidade nova de um explosivo, ou no aperfeiçoamento de alguma máquina de matar. Falência das filosofias, que não veem no homem nada mais que seu uniforme, e que se engenham em dar-lhe justificativas a fim de que não se envergonhe da funçáo que o mandaram desempenhar. Falência da arte, que para nada mais serve que propor a melhor camuflagem, falência da literatura, simples apêndice ao comunicado militar. Falência universal de uma civilização que se volta contra si mesma e se devora.

Em função desse diagnóstico, podemos ter uma noção da dimensão do problema que o surrealismo tem em mira, ao buscar de modo radical reabilitar a imaginação para a vida. Um problema, vale notar, que, como o próprio diagnóstico acima demonstra, vai muito além de uma questão puramente estética. Apesar de o movimento surrealista se formar num meio artístico, procura uma saída revolucionária, inicialmente num plano espiritual, sem nenhuma pretensão de renovar a instituição "arte" ou "literatura", pelo contrário, propõe diluir os limites entre arte e vida.

O que interessa ao surrealismo, na imaginação ilimitada e nas imagens produzidas pela criança, no delírio livre do louco, bem como em outras experiências com caráter inebriante, como na hipnose, no uso de drogas, na paixão amorosa, na escrita automática, no sonho ${ }^{4}$, não é tanto a capacidade de representar coisas reais ou irreais, mas a fascinante intensidade que essas coisas imaginadas podem adquirir, naquele que imagina, envolvendo-o e conduzindo-o de tal sorte que ele parece viver, sentir prazerosa ou dolorosamente o imaginado. $\mathrm{O}$ imaginado, a imagem, ganha aqui estatuto de realidade. Trata-se de uma realidade fantástica, a qual, por se fundar na intensidade dos desejos que mobilizam e sentimentos que produzem, torna secundária a coerência tanto das coisas imaginadas entre si como entre estas e o que chamaríamos de coisas da realidade comum ou sumária.

O que Breton pleiteia, no entanto, não é que desfrutemos levianamente a embriaguez do jogo da imaginação. Pelo contrário, propóe levarmos a sério a realidade a que somos remetidos por ela, além dos caminhos que nos indica em função da intensidade que nos assola e de seu poder de maravilhamento.

\footnotetext{
${ }^{4}$ É a partir da experiência do sonho, objeto privilegiado das investigações dos surrealistas, que Breton, no Manifesto de 1924, irá buscar explicitar o que é a surrealidade. São as descobertas de Freud que dão uma base segura para Breton acreditar que o homem, em suas investigaçôes, pode ir além da realidade sumária e que possivelmente "a imaginaçáo esteja prestes as recobrar seus direitos" (BRETON, 2001, p. 23).
} 
Nesse sentido, Breton toma como paradigma a fantasia onírica e, partindo da posição de Freud, segundo a qual pelo sonho temos acesso à imensa realidade do inconsciente e dos desejos, se pergunta: "Por que não hei de esperar das pistas que o sonho me fornece mais do que espero de um grau de consciência mais elevado? Porventura também o sonho não pode ser usado na resolução das questôes mais fundamentais da vida?" (BRETON, 2001, p. 26) 5 .

Do mesmo modo, não se trata meramente de opor a realidade inconsciente, onírica, fantástica ou imaginada, à realidade da consciência desperta, pois, como Breton em nota de rodapé diz, de forma lapidar: "o que há de admirável no fantástico é que não guarda mais nada de fantástico: não é outra coisa que o real" (BRETON, 1963, p. 25). O que se busca é chegar a um ponto onde a dicotomia entre sonho e vigília náo apareça de maneira táo estanque, onde se possa partir de uma comunicação e relação estreita e vital entre esses dois estados. Esse ponto é a surrealidade (BRETON, 2001, p. 28), que não é, assim, a negação do que chamamos normalmente de realidade, mas uma ampliação e modulação corajosa desta, na qual o homem se apreende em toda sua inteireza, sem receio de "manter em estado anárquico o bando cada dia mais temível de seus desejos" (BRETON, 2001, p. 33). Esse seria então o homem íntegro, capaz de maravilhar-se e, sobre esse maravilhamento, com ousadia e grandeza de espírito, lançar as bases de um mundo e de um cotidiano vitalmente significativos, portanto, de transformar o mundo estreito, carente de experiência e em crise, por causa da atrofia da imaginação.

O caminho privilegiado para se explorar essa experiência do maravilhoso se constitui e se estrutura como imagem ou fluxo de imagens na mente. Vale ressaltar que imagem aqui é concebida num sentido mais amplo, não se tratando só de imagem visual. Em dois momentos do Manifesto de 1924, Breton esclarece mais diretamente o que é e como se estrutura essa imagem tão soberana, o que nos permitirá entender melhor como a imagem surrealista implica uma ampliação ou aprofundamento da realidade, bem como confrontá-la com o conceito de imagem dialética em Walter Benjamin.

Num primeiro momento, Breton, ao descrever como ele mesmo chegou à concepção da escrita automática, apresenta a definição de imagem de Pierre Reverdy (apud BRETON, 2001, p. 35):

\footnotetext{
${ }^{5}$ Breton indaga, por exemplo, quando nẫo se sabe dizer de onde vem a impressão causada por uma ideia ou uma mulher, atribuindo isso desesperadamente ao destino ou ao acaso, se o que se ama nessa ideia ou mulher não "seja exatamente o que a vincula a seu sonho, o que a acorrenta a dados que, por culpa sua se perderam?” (BRETON, 2001, p. 27).
} 
A imagem é uma criação pura do espírito. Ela não pode nascer de uma comparação, mas da aproximação de duas realidades mais ou menos afastadas. Quanto mais as relaçóes das duas realidades aproximadas forem longínquas e justas, mais a imagem será forte, mais força emotiva e realidade poética ela terá.

Breton explica que só veio a compreender o que essa definição de Reverdy queria dizer, quando, insatisfeito com o modo como vinha escrevendo poesia, experimentou ele mesmo, certa vez, antes de adormecer, uma revelação imagética, onde a frase "há um homem partido ao meio pela janela" se destacou e veio acompanhada de sua representação visual, e a janela passou a seguir o movimento do homem. Breton deu crédito a essa experiência quando, não podendo se desvencilhar de tal imagem, esta provocou nele um fluxo de frases/imagens surpreendentes, gratuitas, carentes da autoridade do "eu", como uma briga ocorrendo dentro de si. A partir dessa experiência, da definição de Reverdy e do pensamento falado segundo Freud é que chegou com Philippe Soupault a formular e explorar o que chamou de "escrita automática". Esta teria precisamente o mérito de produzir imagens tão intensas e fantásticas, como as do sonho, e foi, por isso, a base para a conhecida definiçáo do surrealismo dada no primeiro manifesto (BRETON, 2001, p. 40). Ressaltemos somente, nesta pequena meditação de Breton sobre como chegou à escrita automática, o fato de que ele acrescenta à definição de Reverdy o caráter involuntário dessa aproximação de duas realidades heterogêneas, ou seja, ela ocorre independentemente da atividade consciente do "eu", daí este ser surpreendido pela imagem.

É esse aspecto involuntário que será acentuado no segundo momento, quando Breton apresenta a estrutura da imagem surrealista. Nesse sentido, afirma ser o surrealismo ou a imagem surrealista um vício novo, que não se pode adotar ou abandonar ao bel-prazer. As imagens surrealistas seriam como as do ópio, no sentido com que Baudelaire descreve estas últimas, diante das quais a vontade não tem mais força e não governa mais as faculdades. Breton, por isso, diz não acreditar, por exemplo, que numa frase de Reverdy, como "O dia se abriu como uma toalha branca", haja alguma intencionalidade ou atividade consciente na apreensão dessa aproximação entre duas realidades. Assim explica Breton (2001, p. 53) como se produz a imagem surrealista: 
Foi da aproximação, de certo modo fortuita, dos dois termos que jorrou uma luz particular, a luz de imagem, a qual nos mostramos infinitamente sensíveis. O valor da imagem depende da beleza da centelha obtida; ela é, por conseguinte, função da diferença de potencial dos dois condutores. Quando esta diferença mal existe, como na comparação, a centelha não se produz. Ora, o homem não pode, segundo entendo, efetuar a aproximação de duas realidades tão distantes. [...] Cumpre, pois, admitir que os dois termos da imagem não são deduzidos um do outro pela mente tendo em vista a centelha a produzir: eles são produtos simultâneos da atividade que chamo de surrealista, limitando-se a razáo a constatar e apreciar o fenômeno luminoso.

A mente inicialmente tem um papel passivo de observação ou contemplaçáo, mas, aos poucos, se convence da "realidade suprema" dessas imagens:

Logo percebe que elas lisonjeiam a razáo e alargam, outro tanto, seu conhecimento. Enfim, ela toma conhecimento das extensóes ilimitadas onde se manifestam seus desejos, onde os prós e os contras se reduzem sem cessar, onde sua escuridade não a trai. Ela vai, transportada por essas imagens que a arrebatam, que mal lhe dáo tempo de assoprar o fogo de seus dedos. É esta a mais bela das noites, a noite dos relâmpagos: comparado com ela, o dia é como a noite (BRETON, 2001, p. 54).

A imagem surrealista, assim, se estrutura como a aproximação de duas realidades distantes, onde cada um de seus elementos mantém sua singularidade e heterogeneidade, não havendo redução quantitativo-abstrata de um ao outro, nem síntese qualitativo-dialética que permita identificar concretamente um ao outro. Nesse sentido, Octavio Paz (1996, p. 38) assevera que “[...] toda imagem [poética] aproxima ou conjuga realidades opostas, indiferentes ou distanciadas entre si. Isto é, submete à unidade a pluralidade do real". Certamente, ainda segundo Paz, conceitos e leis científicas também operam uma tal redução, mas de modo empobrecedor, seja por meio de uma abstração quantitativa que possibilita dizer que $1 \mathrm{~kg}$ de pedra é igual a $1 \mathrm{~kg}$ de plumas, seja, por uma lógica dialética, a qual transforma a contradição entre os dois termos em um terceiro momento, que suspende tal contradição. O poeta, por sua vez, nomeia as coisas: pluma é pluma, pedra é pedra - e surpreende, ao dizer categoricamente: "a pluma é pedra". Surpresa, podemos acrescentar, que a criança conhece muito bem, ao se divertir com a pergunta: o que é mais pesado, um quilo de algodão ou um quilo de chumbo? Ou que nos desconcerta também em pinturas, como aqueles elefantes com pernas de inseto pintados por Salvador Dali. Assim, Paz (1996, p. 38) assinala 
que, nas imagens poéticas (e nas do humor), “[o]s elementos da imagem não perdem o seu caráter concreto e singular: as pedras continuam sendo pedras [...]: pedras pesadas. E as plumas, plumas: leves. A imagem resulta escandalosa porque desafia o princípio de contradição: o pesado é o ligeiro. Ao enunciar a identidade dos contrários, atenta contra os fundamentos do nosso pensar." ${ }^{\circ}$

Humor, imagens poéticas ou visuais podem, com isso, apresentar uma realidade que o discurso lógico-linear privilegiado pela tradição do pensamento ocidental e a linguagem enquanto representação não atingem. Em função dessa irredutibilidade, dessa diferença de potencial, a aproximação dessas realidades gera uma tensão e uma descarga emotiva, um choque em forma de centelha relampejante que ilumina e torna clara a proximidade desses dois polos e revela uma nova dimensão do real, ou mesmo uma nova realidade, uma "realidade poética" (segundo Reverdy), a qual vincula de maneira insuspeitada e casual aquelas duas realidades.

Por ser uma aproximação involuntária e inesperada, esse choque é tanto maior para o eu-racional e tanto mais desafiador do pensamento lógicoconceitual. É, assim, uma interrupção do fluxo contínuo e confortável deste, um enfraquecimento do controle racional do eu, da cadeia de raciocínios dedutivos, já que esta não pode apreender como duas realidades contraditórias e irredutíveis se aproximam e se apresentam numa mesma imagem. E isso, antes de ser uma negação do pensamento e da linguagem como um todo, é somente uma ampliação de suas possibilidades. Trata-se de uma "luz de imagem", ocorrendo aqui uma revelação, uma iluminação, que traz conhecimento de nós e do mundo, mas, diferentemente das luzes/claróes do Esclarecimento, as quais se limitam à luz racional-diurna e, portanto, iluminam o mundo somente a partir de dicotomias estanques (claro-escuro, eu-mundo, sujeito-objeto, razãosensibilidade, sono-vigília), o conhecimento buscado pelos surrealistas, enquanto pautado, como vimos acima, numa "noite de relâmpagos onde, comparado com ela, o dia é como a noite", implicaria também uma superação das dicotomias, sobretudo uma reconciliaçáo do homem consigo mesmo e com o mundo.

Não é o caso, portanto, de abandonar a razão, lançando-se num retorno ao imediato, porém, como diz Ferdinand Alquié (1955, p. 148-149), de buscar tudo aquilo que se perdeu com a razão. Busca-se uma outra razão:

${ }^{6}$ Escreve Aragon: "Sem dúvida a imagem não é o concreto, mas a consciência possível, a maior consciência possível do concreto. [...] Não há, em essência, uma maneira de pensar que não seja uma imagem. [...] É particular da imagem poética, [...] comportar esse caráter de materialização que tem sobre o homem um grande poder e que o faria crer numa impossibilidade lógica em nome de sua lógica. A imagem poética apresenta-se sob a forma do fato, com tudo o que lhe é necessário" (ARAGON, 1996, p. 225). 
Não é mais a razão técnica, ou científica, em relação a qual o surrealismo não cansou de mostrar o quanto foi incapaz de conter a riqueza do mundo, mas uma nova [razão] onde o homem todo inteiro pode reencontrar sua imagem [...]. O surrealismo abriu o caminho para as démarches dessa razão [...] ao mostrar que o contato com o imediato contém ele mesmo sua claridade. E a claridade é sempre a mesma, que se a busque nos encontros do acaso, na poesia ou no amor. Antes do surrealismo, o maravilhamento diante dos encontros estava abandonado à superstição, o amor à psicologia, a emoção poética à literatura. O surrealismo estabeleceu que esses estados contêm todos a mesma esperança, que todos eles revelam de maneira análoga a relação do homem com o real.

Peter Bürger defende, num vocabulário mais próximo da teoria crítica que nos interessa aqui, que essa busca de reabilitação da imaginação, do sonho, da loucura não consiste em irracionalismo, mas em uma crítica consciente da irracionalidade da "razão instrumental", de uma razão subjugada à "lei da utilidade”. Não é, por conseguinte, reação cega e inconsciente ao mundo pós-I Guerra, contudo, uma resposta consciente, refletida, propondo que o homem se utilize de todas as suas faculdades (BÜRGER, 1996, p. 68).

A manifestaçáo de uma outra realidade ocasionada pela imagem surrealista pode ser entendida como uma espécie de transcendência na imanência, de um distanciamento no interior mesmo do que está próximo, já que se trata da aproximação de duas realidades imanentes a nosso mundo, que nos faz ir além da mera positividade pragmático-racional do mesmo, mas sem apelar para um mundo exterior a este. Recorre, antes, a outras dimensóes (espirituais, poéticas, inconscientes) do mesmo mundo.

Por fim, vale acrescentar que, para Breton, a imagem surrealista, como uma espécie de vício, "cria um certo estado de necessidade e pode impelir o homem a terríveis revoltas" (BRETON, 2001, p. 52). Ou, conforme destaca Aragon (1996, p. 93):

O vício chamado surrealismo é o emprego desregrado e passional da estupefaciente imagem, ou melhor, da provocação sem controle da imagem por ela mesma e por aquilo que ela traz consigo no domínio da representação de perturbações imprevisíveis e metamorfoses. Pois cada imagem a cada lance força-os [homens] a revisar todo o universo. E há para cada homem uma imagem a encontrar que aniquila todo o universo. 
Assim, o maravilhamento que a imagem surrealista explora não é puramente passivo e póe em jogo toda a realidade comum, desafiando-a a um modo de vida mais intenso e íntegro, carregando todo o risco e perigo que isso implica, inclusive como motivação para transformação do mundo.

É todo esse potencial da imagem que estaria ausente numa frase meramente descritiva como a citada anteriormente por Breton: "A marquesa saiu às cinco horas". Tudo isso, ao contrário, é que estaria implicado numa frase como "Uma igreja se erguia resplandecente como um sino", de Philippe Soupault, que Breton cita juntamente com outras, em sua breve tipologia de imagens surrealistas enumeradas no Manifesto surrealista de 1924. Por exemplo:

$\mathrm{O}$ orvalho com cabeça de gata ninava-se na ponte. André Breton. [...] Na floresta incendiada. Os leóes estavam frescos. Roger Vitrac. A cor das meias de uma mulher não é, necessariamente, à imagem de meus olhos, o que levou um filósofo, cujo nome não vem ao caso, a dizer: 'Os cefalópodes têm mais razóes para odiar o progresso que os quadrúpedes'. Max Morise (BRETON, 2001, p. 55).

\section{IluminaÇáo Profana, dialÉTiCa da EMbriagueZ E ESPAÇO DE IMAGEM (BILDRAUM)}

Em seu ensaio "Surrealismo: o último instantâneo da inteligência europeia”, de 1929, Walter Benjamin denomina "iluminação profana” esse tipo de experiência e revelação que os surrealistas exploravam, por meio da "luz de imagem" e que se manifestavam, entre outras, nessas frases fantásticas, humorísticas, escandalosas. Benjamin reconhece, mesmo que com certas ressalvas, como veremos, o potencial crítico e revolucionário implicado nessas experiências, que de fato explodiam por dentro o domínio da literatura na pretensão de dissolver a arte na vida. Isso transparece já na descrição que Benjamin (2012b, p. 22-23) faz da fase heroica ${ }^{7}$ do movimento:

\footnotetext{
7 Essa periodização de Benjamin coincide com a que Maurice Nadeau estabeleceu, em sua História do Surrealismo. Para Nadeau, o período heroico vai de 1923 a 1925, compreendendo o distanciamento com o dadaísmo e outras polêmicas, as primeiras experimentaçôes com sonhos, açóes e jogos coletivos, publicaçôes em revistas, textos fundantes de 1924, como a Vague de rêves, de Louis Aragon, e "O primeiro manifesto surrealista”, de André Breton, a criaçâo da Central Surrealista, com Antonin Artaud. Esse período se encerraria em torno de 1925, a partir dos debates e do posicionamento político do grupo em relaçâo à Guerra de Marrocos, inaugurando o que Nadeau chama de "período raciocinante" (1925-1930) e que Benjamin caracteriza como politização do movimento (Ver: NADEAU, 2008, p. 45s.).
} 
A vida só parecia digna de ser vivida quando o limiar entre o sono e a vigília, em cada um, se desgastava como que pela passagem de imagens ondulantes, indo e vindo em massa, e a linguagem só parecia ser ela mesma quando o som e a imagem, a imagem e o som, se interpenetravam, com exatidão automática, de forma tão feliz que não sobrava a mínima fresta para inserir a pequena moeda a que chamamos 'sentido'. A imagem e a linguagem têm precedência. [...] / E não apenas com relação ao sentido. Também com relação ao eu. $\mathrm{Na}$ estrutura do mundo, o sonho afrouxa a individualidade, como um dente oco. Esse afrouxamento do Eu pela embriaguez é ao mesmo tempo a experiência viva e fecunda que permitiu a esses homens fugir ao fascínio da embriaguez. [...] Quem percebeu que não se trata, nas obras deste círculo, de literatura, mas de algo distinto manifestação, palavra, documento, blefe, ou, se se quiser, falsificação, tudo menos literatura -, sabe também, com isso, que são experiências que estão em jogo, não teorias, e muito menos fantasmas. E essas experiências náo se limitam de modo algum ao sonho, ao consumo de haxixe ou de ópio. É um grande erro supor que das 'experiências surrealistas' conheceríamos somente os êxtases religiosos ou os êxtases produzidos pela droga. [...] A superação autêntica e criadora da iluminação religiosa [...] não se dá através do narcótico. Ela se dá numa iluminação profana, de inspiração materialista e antropológica. ${ }^{8}$

A iluminação profana, assim, é gerada pela embriaguez, por um afrouxamento do eu, por meio do qual este recua para segundo plano e é conduzido por um desdobramento oferecido autonomamente na própria imagem ou nos meandros da linguagem. Esta, por sua vez, é entendida em sua dimensão figurativa, não como instrumento de comunicação de sentidos convencionais e dentro de uma sintaxe enrijecida e pré-determinada, mas enquanto articulação entre som e imagem, a qual aproxima, de modo inusitado, realidades díspares, forjando outros sentidos e sintaxes possíveis (FAVARETTO, 2007, p. 114-115). É importante destacar, pois este é o veio principal do ensaio, onde Benjamin de antemão afirma que náo se trata de entrega total à embriaguez, contudo, de transformá-la em experiência efetiva e transformadora, o que não ocorre por si nem no sonho, nem nas drogas, nem mesmo na religiáo, mas no que Benjamin define, sem explicitar em detalhes, como materialismo antropológico. Não se trata também de êxtase romântico pelo enigmático, maravilhoso, porém, de uma dialética da embriaguez e sobriedade, de uma "embriaguez-sóbria". Essa embriaguez pode se instaurar

8 Tradução modificada por mim; ver: BENJAMIN, 1991, Gesammelte Schriften II, p. 296-297. (A partir de agora, citado como $G S$, seguido do volume em algarismos romanos, página em algarismos arábicos). 
de forma efetiva, mais do que no uso de narcóticos, em atividades muito comuns, como o próprio Benjamin (2012b, p. 33) diz, mais à frente:

Toda investigação séria dos dons e fenômenos ocultos, surrealistas, fantasmagóricos, tem por pressuposto um entrecruzamento dialético do qual o espírito romântico não pode jamais se apropriar. Pois não nos serve de nada sublinhar patética ou fanaticamente no enigmático o seu lado enigmático; muito antes, só penetramos o mistério na medida em que o reencontramos no cotidiano, graças a uma ótica dialética que vê o cotidiano como impenetrável e o impenetrável como cotidiano. A investigação mais apaixonada dos fenômenos telepáticos, por exemplo, ensina-nos muito menos sobre a leitura (processo eminentemente telepático) do que a iluminação profana da leitura pode ensinar-nos sobre os fenômenos telepáticos. [...] O leitor, aquele que pensa, o que espera, o flâneur, sáo tipos de iluminados do mesmo modo que o comedor de ópio, o sonhador, o ébrio. E são iluminados mais profanos. Para não falar daquela mais terrível de todas as drogas - nós mesmos - que tomamos quando em solidão. ${ }^{9}$

É, então, por meio da iluminação profana, materialista, dessa espécie de embriaguez-sóbria, que, para Benjamin, num diagnóstico semelhante aos de Ferdinand Alquié, Octávio Paz e Peter Bürger, os surrealistas conseguiriam forçar os limites da linguagem para além de sua dimensão semióticoinstrumental, forçar o nosso pensamento para além do discurso lógico-racional e, com isso, forçar a nossa percepção do real e nossa ação concreta para além de sua dimensão pragmática e positivista. ${ }^{10}$ Nesse sentido, Benjamin busca nesse ensaio equacionar o elemento de embriaguez e de revolta anárquica dessas experiências de iluminação profana, com seu potencial revolucionário político concreto, ou seja, de cumprir as exigências, que, para ele, permeavam todas as experiências dos surrealistas, de "mobilizar para a revolução as energias da embriaguez” (BENJAMIN, 2012b, p. 34). Tal equação, nesse período, ganhava contorno mais explícito nos debates e reflexóes dos surrealistas sobre se deveriam ou não adotar a militância política no Partido Comunista. Ou seja, momento de tensão e decisão entre permanecer nas ações espontâneas,

\footnotetext{
${ }^{9}$ Tradução modificada por mim; ver: GS II, 307-308.

${ }^{10}$ Tal apreensão é muito próxima da exploração de uma linguagem originária enquanto experiência poética verdadeira, preocupação presente já nos românticos e que Benjamin compartilha, desde seus primeiros escritos sobre Hölderlin, ou nos ensaios a "Linguagem dos homens e a linguagem em geral" e "A tarefa do tradutor". A exposição que Octavio Paz faz do conceito de "imagem" que, em parte, citamos acima, bem como sua apresentaçấo de Breton possuem, apesar de no contexto diferente dos anos 1950, muitos pontos em comum com essa problemática benjaminiana; ver, respectivamente: "Imagem" e "Breton ou a busca do início", em Signos em rotação (PAZ, 1996).
} 
escandalosas e de revolta antiburguesas e antissociais, continuando as experimentaçóes surreais em busca somente de uma transformação espiritual ou de inserir-se no quadro de uma disciplina partidária e ação revolucionária metódica.

Benjamin mesmo se inclui nesse debate, assumindo uma posição própria (GATTI, 2009, p. 91-92), que não seria nem de manter-se nas experimentaçóes surrealistas enquanto transformaçóes puramente espirituais (opção defendida por Antonin Artaud), nem abandonar completamente as experiências surrealistas para questóes mais urgentes de militância partidária e luta política pela revolução comunista (como exigia Pierre Naville), nem atuar paralelamente nessas duas linhas, buscando uma conciliação (como defendia Breton). Podemos dizer que Benjamin aposta na possibilidade de se apreender as duas dimensóes da revolução, a espiritual e a material, por meio daquela dialética da embriaguez. ${ }^{11}$ Essa possibilidade estrutura a argumentação do ensaio e determina os momentos nas obras e açóes dos surrealistas que Benjamin destaca, a fim de elucidar as características da iluminação profana.

Nesse sentido, por exemplo, é que aponta como verdadeira iluminação profana a conclusão de Breton, em seu livro Nadja, de que nos saques ocorridos no Boulevard Bonne-Nouvelle, por ocasião da execução dos anarquistas Sacco e Vanzetti, estariam se cumprindo as promessas estratégicas de revolta contidas desde sempre no próprio nome daquele boulevard. Ou, quando Breton descreve seu livro Nadja como uma casa de vidro onde o autor mora ou como um livro de portas abertas, o que para Benjamin seria uma virtude revolucionária, pois se trata de embriaguez advinda de um exibicionismo moral que denuncia como a virtude aristocrática da discrição se degenerou em "oportunismo de pequenos burgueses arrivistas" (BENJAMIN, 2012b, p. 24; GS II, 298). A iluminação profana ocorreria também por meio da dialética da embriaguez presente no tipo já ultrapassado de amor, a só um tempo extático e casto, entre Breton e Nadja, semelhante ao amor cortês medieval. Ou, ainda, na forte atração que as coisas antiquadas, envelhecidas exercem sobre o casal, fazendo-os perceber as "energias revolucionárias" nelas contidas; também na capacidade dos surrealistas perceberem como "a miséria, não só a social

\footnotetext{
${ }^{11}$ Segundo Luciano Gatti, "embora a posição de Naville seja decisiva para ele [Benjamin], ela exige o abandono de elementos decisivos que Benjamin valoriza na primeira fase do movimento. Sua posição busca encontrar o surrealismo a mobilização para a revolução das energias da embriaguez. Isso significa que ele não defende um abandono da fase mágica do surrealismo, como Naville, mas a sua efetiva realização na política. Nesse sentido, Benjamin busca uma articulação entre a embriaguez da primeira fase com o compromisso e com o pessimismo revolucionário de Naville” (GATTI, 2009, p. 92).
} 
como também a arquitetônica, a miséria dos interiores, as coisas escravizadas e escravizantes, transformam-se em niilismo revolucionário" (BENJAMIN, 2012b, p. 25; GS II, 299).

Capacidade é caracterizada por Benjamin como um "truque" que, nesse mundo de coisas, "troca o olhar histórico sobre o ocorrido pelo olhar político" (BENJAMIN, GS II, 300; 2012b, p. 26), atribuindo à experiência gerada pela imagem surrealista uma noção de sua própria teoria da história, presente já nos primeiros esboços sobre as passagens parisienses que estava redigindo nessa época. ${ }^{12}$ Essa posição se confirma também em relação às ressalvas feitas por Benjamin ao surrealismo e se voltarão sobre as açôes destes onde está ausente aquele tipo de revolta pautada em uma crítica do presente, por meio de um olhar político sobre o passado, sobre as coisas e nomes na cidade. Por exemplo, quando procuram videntes, não como forma de explorar um fenômeno de superfície da sociedade burguesa, denunciando-o como seu avesso complementar, mas para efetivamente consultá-las sobre o futuro. ${ }^{13}$

Portanto, é por meio daquela embriaguez-sóbria que a iluminação profana se constituiria e conteria uma dimensão política de cunho materialista e histórico, a qual permite a Benjamin ver, no surrealismo, a posição mais avançada, na época, no que diz respeito aos propósitos da revolução. A iluminação profana já efetivaria ela mesma, assim, a proposta que Pierre Naville estava fazendo ao grupo e sintetizou na fórmula "organização do pessimismo". Benjamin retoma tal fórmula, pois remete diretamente ao ponto onde a imagem surrealista pode operar politicamente, de modo concreto. A saber: como crítica radical do otimismo ingênuo subjacente ao moralismo e

12 Ver: "A revolução copernicana na visâo histórica é a seguinte: considerava-se o 'ocorrido' o ponto fixo e via-se o presente empenhado em aproximar-se tateando o conhecimento deste elemento fixo. Agora esta relaçẫo deve se inverter e o ocorrido deve adquirir sua fixação dialética da síntese que o despertar realiza com as imagens oníricas contrárias. A política recebe o primado sobre a história. $\mathrm{E}$ os 'fatos' históricos tornam-se algo que acabou de nos acontecer: constatá-los é tarefa da recordaçáo." BENJAMIN (2006, p. 926). Ver também: "A maneira como o passado se adequa à sua própria atualidade superior é determinada e criada pela imagem enquanto a qual e sob a qual é compreendido. - Tratar o passado, ou melhor: tratar o ocorrido, não como se fez até agora, segundo o método histórico, mas segundo o método político" $<\mathrm{O}^{\circ}, 5>$, (2006, p. 939) (Tradução modificada por mim; ver: GS V, 1026). Ver ainda a reelaboração desse último fragmento em $[K 2,3]$ (2006, p. 437).

${ }^{13}$ Atitude que vai ao encontro da compreensão benjaminiana de história, como também já formulada nos primeiros esboços da obra das Passagens, elaborados nessa época e que serão tratados mais à frente, bem como na sua última obra, as teses "Sobre o conceito de história" de 1940. Conferir também a imagem de pensamento "Madame Ariane, segundo pátio à esquerda", de Rua de mão única, na qual Benjamin (1994) opóe a interrogação vazia e submissa do futuro, pois incapaz de perceber as verdadeiras chances e sinais que o presente traz, à presença de espírito, que propicia uma ação oportuna e criadora de futuro diante desses sinais. 
filisteísmo burguês, particularmente da inteligência burguesa de esquerda, que vincula moral idealista e prática política. Otimismo que se manifesta em uma "péssima poesia primaveril, saturada até estourar de metáforas (Vergleichen)", tais como aparecem nos programas dos partidos burgueses:

O socialista vê 'aquele futuro mais belo de nossos filhos e netos' no fato de que todos agem 'como se fossem anjos', cada um possui tanto 'como se fosse rico' e vive 'como se fosse livre'. De anjos, riqueza, liberdade, nenhum vestígio. Tudo somente imagens. E o tesouro de imagens desses poetas de agremiaçáo da social democracia? Seu gradus ad Parnasum? O otimismo (BENJAMIN, GS II, 308; ver: 2012b, p. 34).

A imagem surrealista, no sentido forte que o surrealismo lhe deu, tal como vimos acima, ao tratar do "Manifesto surrealista de 1924" de Breton, atuaria, assim, no plano político, mais precisamente no plano do discurso e imaginário político, combatendo essas metáforas ou meras comparações fundadas num otimismo vazio e na ideologia do progresso, colocando em xeque, dessa forma, as açóes concretas motivadas por esse otimismo. Aqui, Benjamin recorre à distinção entre metáfora (enquanto mera comparação) e imagem, feita por Louis Aragon, no seu livro Traité du style, de $1928^{14}$, defendendo que é no contexto político que essa distinção se torna mais contundente: "Organizar o pessimismo significa simplesmente extirpar a metáfora moral da esfera da política, e descobrir no espaço da ação política o espaço completo da imagem (Bildraum)" (BENJAMIN, 2012b, p. 34). Esta seria, pois, a tarefa decisiva que a imagem, tal como descoberta e explorada pelo surrealismo, que não é acessível pela contemplação tradicional, pode cumprir. ${ }^{15}$ Por meio desta é que o artista pode não só derrubar a hegemonia intelectual burguesa como, o que é mais difícil, se aproximar das massas, ao atuar nos lugares importantes e estratégicos daquele "espaço de imagens":

As pilhérias que ele conta tornar-se-iam melhores. E ele as contaria melhor. Pois também na pilhéria, no insulto, no mal-entendido, em toda a parte em que uma açáo produz a imagem a partir de si mesma e é essa imagem, em que a incorpora e devora, em que se perde a própria proximidade de vista - aí abre-se esse espaço de

\footnotetext{
${ }^{14}$ Ver: "Le voisins se sont plaints: ce son des emmerdeurs, cela ne nous fera pas retourner aux métaphores usées, chausser les pantoufles de l'habitude, nous voulons entendre parler un langage de catapulte, à crouler les plafonds, à décorner les boeufs. La poésie est par essence orageuse, et chaque image doit produire un cataclysme" (ARAGON, 2011, p. 139-140).

${ }^{15}$ Papel semelhante Benjamin atribuirá mais tarde, em 1936, no ensaio sobre "A obra de arte na época de sua reprodutibilidade técnica” ao cinema, cuja forma de recepção tátil e não contemplativa teria sido preparada pelas experimentações dadaístas e surrealistas.
} 
imagem que procuramos, o mundo em sua atualidade completa e multifacetada, no qual não há lugar para qualquer 'sala confortável' (BENJAMIN, 2012b, p. 35). ${ }^{16}$

Desse modo, portanto, podemos entender como, para Benjamin, a imagem de caráter surrealista, a iluminação profana, opera não só uma transformação da percepção do real, mas também pode provocar uma possível transformação do mesmo, ao nos abrir um "espaço de imagem" (Bildraum), ao qual, segundo Benjamin, os surrealistas teriam transferido "a pátria de uma sociedade sem classes” (BENJAMIN, GS II, p. 798). A iluminação profana, em sua dimensão política enquanto percepção e intervenção político-poética no mundo, nos torna esse espaço familiar.

\section{IMAGEM DIALÉTICA}

Esse posicionamento em relação ao momento de politização pelo qual o movimento surrealista estava passando, o qual Benjamin explicita em seu ensaio de 1929, decorre de sua própria produção filosófico-literária, particularmente no livro Rua de mão única, publicado em 1928, cuja forma de escrita, a imagem de pensamento (Denkbild), reflete tanto a aproximação quanto um distanciamento crítico de Benjamin em relação ao surrealismo. As imagens de pensamento exploram, como a imagem surrealista, o potencial crítico da fantasia disruptiva, mas procuram de modo mais direto extrapolar essa experiência subjetiva para uma dimensão histórica e coletiva mais ampla (FÜRNKÄS, 1988; RAULET, 1987; PINHEIRO MACHADO, 2016). As imagens dialéticas, por sua vez, cujas primeiras formulaçôes datam também do final dos anos 1920, se caracterizarão tanto como uma intensificação dessa dimensão histórica enquanto forma imagética e topográfica (WEIGEL, 1994, p. 55-56), privilegiada da rememoração, quanto como uma explicitação mais precisa do momento casual ou involuntário que está presente nesse processo. Nesse sentido, podem ser entendidas como um desdobramento das imagens de pensamento, pelo qual estas ganham o estatuto de método para a pesquisa histórica, particularmente a do século XIX, tal como o projeto das Passagens, obra inacabada, na qual Benjamin trabalhou de 1927 até sua morte, em 1940. A inspiração inicial desse projeto, como o próprio Benjamin afirmou, em carta a Adorno, foi o livro de Louis Aragon, O camponês de Paris (Carta de 31/05/1935, in: ADORNO, 2012, p. 155).

\footnotetext{
${ }^{16}$ Benjamin retomará essa ideia de mundo pleno nas notas relativas às teses "Sobre o conceito de história”, de que trataremos no final deste artigo.
} 
Tal influência é de fato visível já no pequeno texto intitulado "Passagens", escrito em 1927, quando Benjamin planejava escrever um artigo com Franz Hessel (GS V, 1041-1043; BENJAMIN, 2006, p. 901-902; BOLLE, 2006, p. 899). O texto se inicia, abordando a inauguração pomposa de um corredor de acesso em Paris e comenta o consequente desaparecimento de passagens construídas no século XIX, entre elas, a Passage de l'Opéra, destruída pela abertura do Boulevard Haussmann, e que Aragon explora e descreve na primeira parte de seu livro. Como dizem os autores, algumas das passagens que ainda restam "preservam sob a luz ofuscante e em recantos sombrios um passado que se tornou espaço” (BENJAMIN, 2006, p. 901). Há, assim, uma vida histórica nesses espaços públicos já decadentes, nas suas mercadorias obsoletas, nos ofícios antigos que ainda sobrevivem e são oferecidos ali. Chama a atençáo dos autores também a heterogeneidade das coisas unidas por mera proximidade topográfica, que torna a descrição dessas lojas, coisas, ofícios, por si só bastante surreal:

Caso um sapateiro seja vizinho de uma confeitaria, seus porta-cadarços vão assemelhar-se a fileiras de alcaçuz. [...] Pentes de cor verde-sapo e vermelho-coral nadam como num aquário, trombetas tornam-se conchas. Ocarinas viram cabos de guarda-chuvas, há alpiste nas bacias de uma câmera escura fotográfica (BENJAMIN, 2006, p. 902).

No final do texto, o discurso passa a primeira pessoa. O narrador relata que saiu da passagem e não precisa entrar em outra, dirigindo-se entáo para o arco de triunfo, erigido para Ludovico Magno, em 1808, com pirâmides, leóes e armas esculpidas. No movimento desse pequeno texto, podemos identificar, por conseguinte, tanto uma exploração da experiência surrealista a la Aragon quanto uma indicação da dimensão histórica envolvida nessa experiência, a saber, o século XIX e seu historicismo triunfalista.

Essa relação entre experiência surrealista e história é explicitada com mais detalhes em alguns dos 405 fragmentos filosófico-literários redigidos por Benjamin, entre meados de 1927 e final de 1929 e reunidos sob o título "Passagens Parisienses". ${ }^{17}$ Um fragmento desse período mostra bem em que medida a embriaguez da flânerie produz uma iluminação profana e encontra, na simples disposição topográfica e toponímica das ruas, entrecruzamentos de imagens que propiciam a leitura crítica e histórica da cidade:

\footnotetext{
${ }^{17}$ Esses fragmentos podem ser considerados o texto fundador do trabalho das Passagens. Benjamin transcreveu quase a metade deles para os arquivos tematicamente organizados que compóem as "Notas e Materiais" e que foram ampliados nas fases posteriores do projeto, entre 1929 e 1940. (Ver: BOLLE, 2006, p. 899-900).
} 
Excurso sobre a Place du Maroc. Não apenas a cidade e o intérieur, a cidade e o campo aberto podem se entrecruzar; tais entrecruzamentos podem darse de maneira muito mais concreta. Existe a Place du Maroc em Belleville; este tristonho monte de pedras, com suas habitaçóes populares, tornou-se para mim, quando me deparei com ele numa tarde de domingo, não só o deserto marroquino, mas também e ao mesmo tempo um monumento do imperialismo colonial. Naquela praça, a visão topográfica entrecruzava-se com o significado alegórico e, nem por isso, perdeu seu lugar no coração de Belleville. O poder de despertar semelhante visão é habitualmente reservado aos alucinógenos. E, de fato, os nomes de ruas são em tais casos como substâncias inebriantes que tornam nossa percepção mais rica em esferas e camadas do que a existência comum. Deveríamos levar em consideração o estado ao qual ela nos transportam, sua virtude evocadora [...], mas isso ainda diz pouco, pois o momento decisivo aqui não é a associação e sim a interpenetraçáo e perscrutação das imagens (BENJAMIN, $<\mathrm{O}^{\circ}, 25>$, 2006, p. 933; ver também: [P1a,2], p. 559).

Dessa forma, podemos entender em que sentido Benjamin considera o surrealismo como uma "nova arte do flanar" (BENJAMIN, <Do 1>, 2006, p. 909), a qual instaura um novo passado do século XIX. A experiência surrealista, a errância e a embriaguez do flâneur, é justamente aquela que, aberta e deliberadamente entregue ao acaso e às motivaçóes mais subjetivas, às fantasias oníricas, lúdicas, sensuais, possibilita encontrar, nas coisas cotidianas e próximas, tais objetos carregados de passado, bem como penetrar nos mesmos e compreender as tensóes históricas que operam, em seu interior. Faz isso, na medida em que traz à tona, nas coisas, aquela força dialética que atrai o olhar do historiador:

O ser passado, não ser mais, é o que trabalha com mais paixão nas coisas. É a isso que o historiador confia o seu assunto. Prende-se a essa força e reconhece as coisas como são no momento do não-mais-ser. Tais monumentos de um não-mais-ser são as passagens. E a força que nelas trabalha é a dialética (BENJAMIN, <Do, 4>, 2006, p. 909).

Esboça-se, nesses fragmentos germinais, portanto, uma teoria da história que se funda em uma dialética imanente às coisas, na tensão entre sua existência atual e seu não-mais-ser, cujo acesso é aberto pelas imagens propiciadas pela experiência surrealista ou iluminação profana. É essa experiência que, antes de mais nada, permite um conhecimento dialético e histórico da verdade em um sentido bem tradicional, a saber, como superação das aparências, que 
ao mesmo tempo se coloca, por ser imagem relampejante do agora do náomais-ser nas coisas, como crítica à comodidade do historicismo e da ciência burguesa, bem como à sua ideologia do progresso. É o que podemos ler num fragmento desse período, no qual Benjamin afirma:

O conhecimento histórico da verdade só é possível como superação [Aufhebung] da aparência: essa superação, porém, não deve significar volatização ou atualizaçáo do objeto, e, sim, por sua vez, assumir a configuração de uma imagem veloz. A pequena imagem veloz em oposição à comodidade científica. Essa configuração de uma imagem veloz coincide com o reconhecimento [Agnoszierung] do 'agora' nas coisas. Mas não do futuro. Semblante [Miene] surrealista das coisas no agora, semblante pequeno-burguês [spiessige] no futuro. A aparência que é superada aqui é aquela segundo a qual o tempo anterior estaria no agora. Na verdade: o agora é a imagem mais íntima do ocorrido (BENJAMIN, <O॰ , 81>, 2006, p. 948. Ver: $G S$ V, 1034-1035).

Note-se que Benjamin recorre, nessa passagem, a um termo estrangeiro, Agnoszierung, que significa, em geral, reconhecer, mas também é usado no sentido de identificar uma pessoa ou um cadáver, um morto. $\mathrm{O}$ "reconhecimento do agora nas coisas" é reconhecer o que nas coisas não é mais, ou seja, que as coisas náo são simples coisas, daí ser superaçáo das aparências. Essa escolha terminológica corrobora a caracterização da atenção do historiador como voltada aos "monumentos do não-mais-ser" - tais como as passagens que estavam desaparecendo. O olhar histórico tem por objeto, portanto, o que ainda está aí, mas de alguma forma já não é mais e, por isso, testemunha também o que poderia ter sido e não foi. Assim, Benjamin confronta o historiador com uma profunda tensão existencial, política e social inerente a sua tarefa.

O encontro com o passado, com o ocorrido, não é livre de conflitos, e esses conflitos não se resolvem por meio de uma descrição positiva, linear e cômoda dos fatos, já que estes não são simples fatos, são fatos lembrados e percebidos em configuração com um presente, um agora. E se não é possível constatar comodamente uma linearidade do passado para o presente, muito menos é possível estabelecer uma linearidade do presente para o futuro. Nesse sentido, o olhar do historiador se aproxima daquilo que, como vimos acima, Benjamin caracterizou em seu ensaio sobre o surrealismo como o truque do "niilismo revolucionário" dos surrealistas, o qual transforma olhar histórico sobre o ocorrido em olhar político. ${ }^{18}$ Nesse mesmo sentido, podemos entender

${ }^{18}$ Ver, acima, notas 12 e 13. 
a apropriação benjaminiana da fórmula "pessimismo organizado" de Naville, cujas imagens colocam em xeque as metáforas otimistas oriundas da crença ingênua no progresso linear.

Há, no início do trecho acima, uma referência à dialética hegeliana, da qual Benjamin se apropria, mas em parte se distancia, ao contrastá-la com a imagem veloz de cunho surrealista. Por um lado, em Hegel, só depois que as coisas se realizam em todas as suas potencialidades ou se atualizam é que o pensamento chega efetivamente ao conceito verdadeiro e concreto das mesmas. O conhecimento é, assim, um processo histórico que apreende o ser das coisas em um movimento dialético, negando o que nelas é simples aparência de ser e colocando em jogo não apenas o que as coisas não são mais, mas também o que não são ainda. Até aqui, podemos dizer que Benjamin seguiria Hegel.

Por outro lado, em Hegel, essa atualização é a realização da ideia ou do espírito na história e, no fim, a ênfase recai sobre o espírito enquanto pensamento conceitual ou história do pensamento. Isso significa, como diz Benjamin, que o objeto se volatiza, perde sua materialidade, que é irredutível a qualquer determinação ideal e exterior às coisas mesmas. A imagem gerada pela experiência da iluminação profana, pelo contrário, garante que o pensamento não se restrinja ao conceito e, com isso, não abandone as tensões históricas concretas que as próprias coisas carregam e que podem colocar nossa percepção comum em curto circuito, no momento em que a abordamos. Só desse modo é possível superar a aparência de que o passado seria como um fardo que aprisiona as coisas em uma essência ou lei imutável, do qual não podemos mais nos libertar, e perceber no âmago mesmo do ocorrido aquilo que ele tem de mais atual, crítico e renovador. Essa diferença para com Hegel é mais explícita em outro fragmento dessa mesma época, no qual Benjamin apresenta, não por acaso e pela primeira vez, o conceito de imagem dialética:

Sobre a imagem dialética. Dentro dela situa-se o tempo. Ele já se encontra em Hegel, na dialética. Essa dialética hegeliana, porém, conhece o tempo apenas como tempo propriamente histórico, senão psicológico, como tempo do pensamento. $\mathrm{O}$ diferencial de tempo, no qual apenas a imagem dialética é real, ainda lhe é desconhecido. Tentativa de mostrar isso na moda. O tempo real não entra na imagem dialética em tamanho natural -e muito menos psicologicamente - e sim sob sua forma ínfima. O momento temporal só pode ser totalmente detectado por intermédio da confrontação com um outro conceito. Este conceito é o 'agora da cognoscibilidade' (BENJAMIN, <Qo, 21>, 2006, p. 951, Tradução modificada por mim, ver: $G S V, 1037-1038)$. 
A capacidade de captar no "agora da cognoscibilidade" a tensão ou o diferencial entre ocorrido e agora que está no interior das próprias coisas é característica da imagem veloz produzida pela experiência surrealista. Ela opera, assim, com uma dimensão do tempo histórico diferente do natural, do meramente cronológico ou do psicológico, interno ao sujeito que a percebe, na medida em que todos estes são ainda exteriores às próprias coisas.

Essa diferença que Benjamin aponta entre imagem dialética e dialética de Hegel, no entanto, diz respeito mais ao contexto histórico no qual foram formuladas, do que às concepçóes propriamente ditas. A radicalização da dimensão histórica e política no ser concreto das coisas seria antes uma resposta à radicalização da crise vivida na Europa pós-I Guerra, que abalou a noção ocidental de humanidade e da qual a crise da metafísica e dos grandes sistemas filosóficos, entre eles o de Hegel, é um dos aspectos. Nesse contexto, Benjamin se posiciona muito mais criticamente em relação à concepção da historicidade do ser em Heidegger, contrastando-a igualmente com o surrealismo, como podemos ler no seguinte fragmento dos "Primeiros esboços", na elaboração em que foi transcrito para o arquivo " $S$ " das "Notas e materiais":

Interesse vital em reconhecer um determinado ponto na evolução (Entwicklung) como encruzilhada (Scheideweg). Nesse ponto localiza-se atualmente o novo pensamento histórico, que é caracterizado por uma maior concretude, pela salvação dos períodos de decadência e pela revisão da periodicização, de maneira geral e em particular, e cuja utilizaçáo em um sentido reacionário ou revolucionário está sendo decidida agora. Neste sentido, o que se anuncia nos escritos dos surrealistas e no novo livro de Heidegger é a mesma crise, com suas duas possibilidades de solução (BENJAMIN, [S 1,6], 2006, p. 587). ${ }^{19}$

O surrealismo, assim, oferece para Benjamin uma compreensão da história mais concreta e não triunfalista que a de Hegel e dá, ao contrário de Heidegger, uma resposta emancipadora à crise vivida na Europa de então. Náo cabe aqui aprofundar em detalhes as relaçôes e diferenças de Benjamin para com Hegel ou Heidegger, mas tão somente mostrar em que medida Benjamin recorre ao surrealismo, para se posicionar diante desses pensadores. Cabe agora, isto sim, abordar certa diferença de Benjamin para com o próprio surrealismo. Como já ficou claro no ensaio de 1929, que analisamos acima, a

${ }^{19}$ Tradução modificada por mim, ver: GS V, 676. Ver também: BENJAMIN, <O, 4>, 2006, p. 939; GS V, 1026. O livro de Heidegger a que Benjamin se refere é Sein und Zeit (Ser e tempo), publicado em 1927. Ver: BARCK, 2006, p. 390-391. 
adesão de Benjamin ao movimento surrealista não é de modo algum irrestrita. No que diz respeito aos "Primeiros esboços", vale retomar dois fragmentos nos quais Benjamin estabelece uma clara delimitação entre seu projeto sobre as Passagens e o livro $O$ camponês de Paris, de Aragon, a qual, não obstante, como já vimos, foi uma das principais inspiraçóes desse projeto.

Em um fragmento do esboço "Passagens parisienses $<$ II $>$ "20, há uma pequena genealogia do movimento surrealista, cujo pai seria o movimento vanguardista Dada e a mãe, uma passagem, a saber, a Passage de l'Opéra. Nesta, que foi derrubada logo em seguida, havia um café no qual os integrantes do grupo se reuniam. Segundo Benjamin, Aragon, em seu livro, prestou a essa passagem

a homenagem póstuma mais tocante jamais prestada por um homem à mãe de seu filho. Tal homenagem deve ser lida naquele livro. Aqui, porém, náo se deve esperar nada mais que uma fisiologia e, para dizê-lo francamente, um resultado de dissecaçâo dessas partes mais misteriosas e mais mortas da capital da Europa (BENJAMIN, <hº,1>, 2006, p. 962; tradução modificada por mim; ver: $G S V$, 1057).

Se o surrealismo é capaz de identificar ou reconhecer (Agnoszierung) e trazer à tona, em toda a sua intensidade figurativa, a constelação entre o agora e o ocorrido nas coisas obsoletas, decadentes, mortas, ou seja, nas coisas no momento de seu não mais ser, para Benjamin, resta ainda um trabalho de análise - de dissecação de cadáver - a ser feito nesse material, a fim de localizar com precisão histórica e política o contexto em que aquela constelação se mostra como verdadeira ou emancipadora, em um presente coisificado. Novamente, podemos sustentar que Benjamin está propondo aqui uma espécie de organização racional do pessimismo, não para negar a experiência surrealista, mas para intensificá-la de forma mais consciente e localizá-la em uma perspectiva histórica mais ampla do que a experiência de uma fantasia limitada à esfera subjetiva e individual. $\mathrm{O}$ que, no fragmento acima, se apresenta como uma diferença de perspectiva desses dois autores na abordagem de um objeto, é mais bem explicitado conceitualmente e por meio de um claro distanciamento crítico no segundo:

\footnotetext{
${ }^{20} \mathrm{O}$ esboço "Passagens parisienses <II>", assim intitulado pelos editores alemães, contém fragmentos um pouco mais elaborados. Foi escrito com base nas anotaçōes de "Passagens parisienses $<$ I $>$ "e lido por Benjamin para Gretel, Adorno e Horkheimer, em 1929.
} 
Enquanto Aragon persiste no domínio do sonho, deve ser encontrada aqui a constelação do despertar. Enquanto em Aragon permanece um elemento impressionista - a 'mitologia' - (e a esse impressionismo se devem os muitos filosofemas sem teor do livro), trata-se aqui da dissolução da 'mitologia' no espaço da história. Isso, de fato, só pode acontecer através do despertar de um saber ainda não consciente do ocorrido (BENJAMIN, $<\mathrm{H}^{\circ}, 17>$, 2006, p. 925) ${ }^{21}$.

À primeira vista, esses dois fragmentos podem dar a impressão de que Benjamin estaria abandonando de todo o surrealismo e sua exploração da fantasia onírica, em prol de uma metodologia da história mais racional e fundada na consciência desperta. Um fragmento que corrobora essa impressão é aquele onde Benjamin menciona que se trata, no projeto das Passagens, de seguir com o machado afiado da razão, sem olhar para direita ou para esquerda, para vencer a loucura e o mito que viceja no solo do século XIX (BENJAMIN, $<\mathrm{G}^{\mathrm{o}}, 13>$, 2006, p. 921; GS V, 1010). ${ }^{22}$ Parece, de fato, que Benjamin estaria abandonando aqui a flânerie e as experiências surrealistas. Para Sérgio Paulo Rouanet, esse movimento de Benjamin, o qual se volta não para o sonho, mas para o despertar, é o que o distinguiria verdadeiramente dos surrealistas. Segundo ele, em Benjamin, "não se de trata atribuir um valor cognitivo ao irracional, mas de despertar o passado de seu sonho mítico, em que reinava o irracional" (ROUANET, 1987, p. 92; ver também: p. 121). Rouanet mostra ainda que Benjamin, sem negar o valor dos elementos oníricos como um todo, considera que estes devem ser, em sentido hegeliano, dialeticamente superados no despertar, por isso, não cabe considerar Benjamin como um irracionalista. Náo obstante, mesmo que concordemos que Benjamin não seja irracionalista, não é precisa a afirmação de que ele estaria abandonando de todo o surrealismo. Como explicar, do contrário, as passagens em que ele associa o surrealismo precisamente com o despertar?

Em um dos fragmentos dos "Primeiros esboços", por exemplo, Benjamin afirma que o século XIX nos é ainda muito próximo para ser tomado como tradição ou para ser objeto de coleção, por isso, assim se exprime, em relação ao projeto acerca das passagens:

\footnotetext{
${ }^{21}$ Tradução modificada por mim; ver: GS V, 1014. Esse fragmento foi transcrito posteriormente por Benjamin, sem modificaçóes, para as "Notas e materiais"; ver: BENJAMIN. [N1,9], 2006, p. 500; GS V571-572.

22 Benjamin transcreveu esse fragmento quase literalmente, no começo do "Arquivo N" das "Notas e materiais" ver: BENJAMIN. [N1,4], 2006, p. 499; GS V, 570-571.
} 
Exige-se a reflexão concreta, materialista, sobre o que está mais próximo. A "mitologia", como diz Aragon, recua novamente as coisas para longe. Apenas a apresentação daquilo que nos é familiar e que nos condiciona é importante. O século XIX, para falar juntamente com os surrealistas: são os ruídos que intervêm em nosso sonho, que interpretamos ao despertar (BENJAMIN, <Co,5>, 2006, p. 907-908. Tradução modificada por mim; $G S V, 998)$.

Não se trata, portanto, de forçar um afastamento exterior às coisas por meio do mito para contemplar a exigência de distanciamento histórico que Benjamin, também nesse fragmento, atribui a Aragon e à escola romântica tradicional. Trata-se, pelo contrário, de explorar a possibilidade de abrir um espaço de crítica na proximidade mesma das coisas e de sua surrealidade. $\mathrm{Ou}$ seja, é a experiência surrealista que nos faz encontrar e tomar consciência dos elementos verdadeiros contidos na fantasia onírica, aqueles que apontam para o verdadeiro despertar. ${ }^{23}$ Este não abandona o sonho de todo e nem se esgota na consciência desperta, constitui-se antes como constelação de ambos, ou como uma síntese aberta. Esse seria o espaço de imagem ao qual Benjamin remete, no final do ensaio de 1929, como destacamos acima, concluindo aquele ensaio com a seguinte afirmação:

No momento, os surrealistas são os únicos que conseguiram compreender as palavras de ordem que o Manifesto [comunista, de Marx, FAPM] nos transmite hoje. Eles trocam, um a um, sua mímica facial (Mienenspiel) pelo mostrador de um despertador, que soa, a cada minuto, durante sessenta segundos (BENJAMIN, 2012b, p. 36; tradução modificada por mim, ver: GS II, 310).

Nesse sentido, mais exata é a posição de Michael Löwy, segundo a qual as ressalvas e distanciamento de Benjamin, naquele fragmento do trabalho das Passagens, dizem respeito especificamente ao livro de Aragon e talvez ao período heroico do surrealismo, o da Vague de rêves, não ao surrealismo como um todo ou dos anos 1927-1929. Löwy nota que, no ensaio de 1929, as críticas de Benjamin aos surrealistas não se dão em termos como "mitologia", "impressionismo" ou "filosofemas informes". Por fim, vale ressaltar dois pontos levantados por Löwy: em primeiro lugar, que a imagem do despertador ininterrupto poderia ser lida como a disposição do surrealismo em "considerar ${ }^{23}$ Acerca da diferença entre o verdadeiro despertar e o falso, ver fragmento: BENJAMIN, <ho,3>,
2006, p. 962-963; GS V, 1058. Sobre o sonho em Walter Benjamin, ver: BRETAS, 2016. 
cada segundo como a porta estreita pela qual pode entrar a revolução - para parafrasear uma fórmula que Benjamin só escreverá bem mais tarde" (LÖWY, 2002, p. 53). Em segundo lugar, não cabe atribuir ao pensamento de Benjamin uma identificação estática entre despertar e racionalismo, em oposição a sonho e irracionalismo. Benjamin não trabalha com essas dicotomias clássicas, daí Löwy se perguntar: "a aspiração de Benjamin não é - como a de Baudelaire e de André Breton - a criação de um mundo novo onde a ação seria enfim irmã do sonho?” (LÖWY, 2002, p. 54). Podemos acrescentar que a ação consciente, racional, revolucionária só é verdadeira, quando carrega consigo o sonho.

Mesmo em fases posteriores da obra das Passagens, Benjamin continua associando o surrealismo com o despertar e com o conceito de "agora da cognoscibilidade". É o que podemos ler no seguinte fragmento, onde Benjamin aproxima ainda o surrealismo ao despertar em Proust:

Seria o despertar a síntese da tese da consciência onírica e da antítese da consciência desperta? Nesse caso, o momento do despertar seria idêntico ao "agora da cognoscibilidade", no qual as coisas mostram seu rosto [Miene $]$ verdadeiro - o surrealista. Assim, em Proust, é importante a mobilização da vida inteira em seu ponto de ruptura, dialético ao extremo: o despertar. Proust inicia com uma apresentação do espaço daquele que desperta (BENJAMIN. [N 3a, 3], Passagens, p. 505-506).

Benjamin, dessa maneira, mesmo buscando evitar uma proximidade muito grande com o surrealismo, não abandonou sua intenção de participar filosoficamente da sua herança. ${ }^{24}$ Podemos entender a referência ao despertar em Proust, bem como seu parentesco com o surrealismo, ${ }^{25}$ como uma forma de Benjamin situar a dimensão casual da imagem surrealista nos parâmetros mais sólidos da memória ou rememoração involuntária, o que permitiria elevar essa experiência figurativa subjetiva ao âmbito mais geral e coletivo da história.

\footnotetext{
${ }^{24}$ Ver: "Carta a Scholem de 30/10/1928" in: BENJAMIN, 1978, p. 483. Sete anos mais tarde, em outra carta a Scholem, Benjamin reafirma essa relação comentando que o trabalho na obra das Passagens, "expóe tanto a realização [Verwertung] filosófica do Surrealismo -e com isso sua superaçáo -como igualmente a tentativa de apreender a imagem da história nas fixaçóes mais modestas da existência, em seus detritos" “Carta a Scholem de 09/08/1935” in: BENJAMIN, 1978, p. 683.). Ver também: BARCK, 2006, p. 389.

${ }^{25}$ A relação do despertar em Proust e o trabalho das Passagens está presente já nos primeiros esboços. Ver: BENJAMIN. <hº,2>, 2006, p. 92; GS V, 1057-1058. Benjamin transcreveu esse fragmento em [K1,2], 2006, 433-434; GS V, 491. Em seu ensaio "A imagem de Proust", de 1929, Benjamin afirma que Proust evoca as imagens esvaziando o eu, para saciar sua "nostalgia de um mundo deformado pela semelhança, no qual irrompe o verdadeiro semblante da existência, o surrealista" (BENJAMIN, 2012c, p. 41; GS II, 314).
} 
O conceito de imagem dialética é o resultado mais elaborado dessa apropriação filosófica que Benjamin faz do surrealismo. Vimos detalhadamente como ela foi se constituindo, nos primeiros esboços da obra das Passagens, num movimento de aproximação e afastamento com relação ao surrealismo. Uma rápida análise de sua estrutura, comparando-a com a imagem surrealista, tal como descrita na primeira parte deste artigo, nos possibilitará, agora, entender melhor a persistência de elementos surrealistas na teoria da história de Benjamin. Para tal, é suficiente abordarmos a formulação que dá à imagem dialética, em um fragmento do "Arquivo N" das Passagens:

Imagem é aquilo em que o ocorrido entra em constelação junto com o agora num lampejo. Em outras palavras: imagem é a dialética em estado de repouso. Pois, enquanto a relação do presente com o passado é uma relaçáo puramente temporal, a do ocorrido com o agora é uma relação dialética: não de natureza temporal, mas imagética. Somente as imagens dialéticas são autenticamente históricas, isto é, imagens não-arcaicas. A imagem lida, quer dizer, a imagem no agora da cognoscibilidade, carrega no mais alto grau a marca do momento crítico, perigoso, que subjaz a todo ato de ler (BENJAMIN. [N 3, 1], 2006, p. 504-505; tradução modificada por mim, ver: $G S V$, 578).

A imagem dialética tem, pois, como a imagem surrealista que Breton descreve, no manifesto de 1924, uma estrutura dupla, onde está em jogo um encontro, uma aproximação, a formaçáo de uma constelação, a partir de duas realidades concretas, díspares, heterogêneas e singulares, no caso, o ocorrido e o agora. O conceito de constelação, como uma imagem que se desenha a partir de estrelas singulares, garante justamente que essas singularidades não sejam reduzidas a abstraçóes e subsumidas a um conceito ou lei histórica universal, mas simplesmente sejam agrupadas, associadas por algum tipo de parentesco, visível ou não à primeira vista. Desse modo, a imagem dialética, como forma de rememoraçáo histórica, pode colocar dois momentos históricos em relação disruptiva, rompendo com o tempo histórico em sentido cronológico e linear, e fazendo saltar pelos ares o continuum da história, ao imobilizar ocorrido e agora em uma imagem que lampeja veloz, como a centelha ou a "luz de imagem" buscada pelos surrealistas. Assim como a imagem surrealista abre, por meio do choque, uma nova perspectiva que amplia e dá outra dimensão à nossa realidade cotidiana e reduzida ao pragmático e utilitário, a imagem dialética, igualmente sem apelo a um mundo transcendente, opera uma disrupçáo que coloca a história sob uma dimensão mais ampla e uma 
perspectiva mais profunda, ensejando que se submeta à verdadeira leitura, que é crítica e perigosa, já que pode nos fazer revisar todo o universo no qual nos habituamos comodamente a viver, fazer arte, política, ciência e historiografia também.

Não estamos longe das famosas teses "Sobre o conceito de história", último texto de Benjamin, escrito em 1940. Neste, Benjamin também fala do encontro entre o ocorrido e o tempo do agora (Jetztzeit), ou o "agora da cognoscibilidade", que interrompe o contínuo da história oficial e opressora e deve ser apreendido como uma imagem veloz. Sobre este é que o historiador materialista deve construir seu objeto. O surrealismo não é citado explicitamente. Benjamin recorre antes ao modelo do messianismo judaico para formular sua teoria materialista da história, a saber, o encontro é apreendido como um apelo do passado ao presente, para que este cumpra a esperança fracassada de uma emancipação ou revolução que poderia ter ocorrido, mas não ocorreu. Não obstante, Benjamin continua tratando de imagem. E o modelo messiânico da história, a despeito da proibição da idolatria na tradição judaica, tem semelhança estrutural com o tipo de crítica histórico-materialista do presente que as concepçôes de imagens abordadas ao longo deste artigo exploram.

Além disso, sem podermos entrar em maiores detalhes, vale destacar que, em certas tradiçóes messiânicas judaicas, não se sabe quando e se o messias virá, daí a proibição de especular sobre o futuro e a exigência de permanecer em estado de espera e disponibilidade, a fim de não deixar passar despercebida a brecha pela qual o messias eventualmente irromperá na história. Mutatis mutandis, o surrealismo explora uma disponibilidade para o acaso que seja apta a perceber e levar a sério momentos imprevisíveis, nos quais encontros significativos entre realidades díspares abrem um espaço, dentro do próprio cotidiano, para uma realidade mais ampla. Não surpreende, portanto, que, em nota referente às teses, à qual intitulou "Novas teses K", Benjamin associe o mundo messiânico ao "mundo em sua totalidade completa e multifacetada" ou ao "espaço de imagens" aberto pela iluminação profana, citando inclusive o parágrafo final do seu ensaio sobre o surrealismo (BENJAMIN, GS I, 1234$1235)^{26}$. Dessa forma, também aqui não podemos dizer que Benjamin teria abandonado completamente o surrealismo a favor de um modelo inspirado na teologia messiânica que tanto marcou seu pensamento, desde sua obra de juventude. Importa é que, tanto em um como no outro, Benjamin tem

${ }^{26}$ Tradução para o português de João Barrento, em BENJAMIN, 2012a, p. 180-181. 
uma base para sua crítica à concepção positivista e determinista da história e à coisificação da realidade, crítica que visa ainda a certas correntes do materialismo histórico e do marxismo.

Com isso, identificamos a dimensão, a persistência e os limites da influência do surrealismo na obra literária e filosófica da maturidade de Walter Benjamin. Essa presença, como vimos, não é linear: alterna-se entre fascínio e necessidade de afastamento crítico, entre inspiração central para grandes projetos e confronto e rearranjo com outras influências. $\mathrm{O}$ surrealismo, de qualquer forma, configura um momento incontornável e produtivo, na constelação de tradiçóes, movimentos culturais, correntes de pensamento mais díspares, como a teologia judaica, outras vanguardas, materialismo histórico, psicanálise, que Benjamin mobiliza em sua obra. Constelação dinâmica, reflexiva, na qual cada momento vibra com sua luz, sem reduzir ou ser reduzido a outro, sem uma síntese que os supere, e que têm em comum iluminar, em cada momento oportuno, cada um a seu modo, caminhos possíveis para a crítica e a transformação do presente.

MACHADO, F. A. P. Disruptive images: surreal elements in Walter Benjamin's conception of history. Trans/form/açāo, Marília, v. 43, n. 2, p. 39-70, Abr./Jun., 2020.

\begin{abstract}
In the Surrealistic manifest from 1924, Andre Breton explains the product of surrealistic action as a "light of image" resulting from an arbitrary approach of two distant realities. This double structure of surrealistic image has a disrupting character that breaks our common perception of reality. Thus can open a space for social and historical criticism as well as for an aesthetical-political intervention in a society where traditional forms of criticism seem to be neutralized. Walter Benjamin defines this surrealistic experience and its opened space respectively with the expressions "profane illumination" and "image space" (Bildraum). Both have similarities with Benjamin's ideas of "thought image" and "dialectical image", especially because they were elaborated amidst the cultural european crisis in the 1920 ies looking to find a revolutionary way out of it. Through a comparative analysis of these notions of image, this paper proposes to investigate the influence and the relevance of surrealism for Benjamin's dialectical-figural way of thinking and his comprehension of history.
\end{abstract}

KEYwords: Light of image. Thought imagem. Dialectical image. Walter Benjamin. Surrealism. 


\section{REFERÊNCIAS}

ADORNO, Theodor W. Correspondência 1928-1940 - Adorno-Benjamin. (Tradução José Marcos Mariani de Macedo). São Paulo: Ed. Unesp, 2012.

ALQUIÉ, Ferdinand. La Philosophie du Surrealisme. Paris: Flammarion, 1955.

ARAGON, Louis. O Camponês de Paris. Rio de Janeiro: Imago, 1996.

ARAGON, Louis. Traité du style. Paris: Gallimard, [1928], 2011.

BARCK, Karlheinz. Der Sürrealismus. Die letzte Momentaufnahme der europäischen Intelligenz. In: LINDNER, Burkhardt (Org.). Benjamin Handbuch: Leben-WerkWirkung. Stuttgart/Weimar: Metzler, 2006, p. 386-399.

BENJAMIN, Walter. O anjo da história. (Organização e tradução de João Barrento). Belo Horizonte: Autêntica, 2012a.

BENJAMIN, Walter. Briefe. (Orgs. Gershom Scholem e Theodor W. Adorno). Frankfurt am Main: Suhrkamp, 1978.

BENJAMIN, Walter. Gesammelte Schriften, vol. I-VII. (Editado por Rolf Tiedemann e Hermann Schweppenhäuser). Frankfurt a. M.: Suhrkamp, 1991.

BENJAMIN, Walter. Passagens. (Org. Willi Bolle; Col. Olgária Matos; Trad. de Irene Aron e Cleonice P. B. Mourão). São Paulo: Imp. Oficial/ Belo Horizonte: Ed. UFMG, 2006.

BENJAMIN, Walter. Rua de máo única. (Tradução de Rubens Rodrigues Torres Filho e José Carlos Martins Barbosa). São Paulo: Brasiliense, .4a ed., 1994.

BENJAMIN, Walter. Surrealismo: o último instantâneo da inteligência europeia. In: BENJAMIN, Walter. Magia e técnica, arte e política. (Trad. Paulo Sérgio Rouanet). $8^{\mathrm{a}}$ ed. Revista. São Paulo: Brasiliense, p. 37-50, 2012b. (Obras escolhidas, vol. 1).

BENJAMIN, Walter. A imagem de Proust. In: BENJAMIN, Walter. Magia e técnica, arte e política. (Trad. Paulo Sérgio Rouanet; Rev. Téc. Márcio Seligmann-Silva). $8^{\text {a }}$ ed. São Paulo: Brasiliense, p. 21-36, 2012c. (Obras escolhidas, vol. 1).

BOLLE, Willi. Nota introdutória. In: BENJAMIN, Walter. Passagens. (Org. Willi Bolle; Col. Olgária Matos; Trad. de Irene Aron e Cleonice P. B. Mourão). São Paulo: Imp. Oficial/ Belo Horizonte: Ed. UFMG, p. 899-900, 2006.

BRETAS, Aléxia. Da psique ao mundo das coisas: a materialidade do sonho em Walter Benjamin. Revista Limiar, Guarulhos, vol. 3, nr. 6, p. 62-78, 2. sem. 2016.

BRETON, André. Manifestes du surréalisme. Paris: Gallimard, 1963.

BRETON, André. Manifestos do surrealismo. (Tradução de Sérgio Pachá) Rio de Janeiro: Nau, 2001.

BÜRGER, Peter. Der französische Surrealismus: Studien zur avangardistischen Literatur. 2. erweiterte Auflage. Frankfurt a.M.: Suhrkamp, 1996. 
FAVARETTO, Celso. Tropicália , alegoria, alegria. Cotia-SP: Ateliê Editorial, $4^{\mathrm{a}}$ ed., 2007.

FÜRNKÄS, Josef. Image de pensée et miniature selon W. Benjamin. In: RAULET, G; FÜRNKÄS, J.(Orgs.). Weimar: le tournant esthétique. Paris: Anthropos, p. 288-299, 1988.

GATTI, Luciano. "Walter Benjamin e o surrealismo: escrita e iluminação profana", Artefilosofia, Ouro Preto, nr. 6, p. 74-94, abr. 2009.

LÖWY, M. Walter Benjamin e o surrealismo: história de um encantamento revolucionário. In: LÖWY, M. Estrela da manhá: surrealismo e marxismo. (Tradução Eliana Aguiar) Rio de Janeiro, 2002.

NADEAU, Maurice. História do surrealismo.(Trad: Geraldo G. de Souza) São Paulo: Perspectiva, 2008.

PAZ, Octavio. Imagem. In: PAZ, Octavio. Signos em Rotaçáo. São Paulo: Perspectiva, 1996. PINHEIRO MACHADO, Francisco. Disrupção subjetiva e crítica social: surrealismo e imagens de pensamento benjaminianas. Revista Filosofia e Educaçáo, v. 8, p. 92-111, 2016.

RAULET, Gérard. Einbahnstrasse. In: LINDNER, Burkhardt (Org.). Benjamin Handbuch: Leben-Werk-Wirkung. Stuttgart/Weimar: Metzler, p. 359-373, 2006.

ROUANET, Paulo Sérgio. As razóes do iluminismo. São Paulo: Companhia das Letras, 1987.

WEIGEL, Sigrid. Passagen und Spuren des 'Leib- und Bildraums' in Benjamins Schriften. In: WEIGEL, Sigrid (Org.). Leib- und Bildraum: Lektüren nach Benjamin. Köln/ Weimar/ Wien: Böhlau, p. 49-64, 1992.

Recebido: 27/10/2017

Aceito: 30/6/2019 